\title{
DISCRETE X-RAY SOURCES IN GALAXY CLUSTERS
}

\author{
A.V. Tugay ${ }^{1}$, L.V.Zadorozhna ${ }^{2}$, S.Yu. Shevchenko ${ }^{3}$ \\ 1 Taras Shevchenko National University of Kyiv, \\ Kyiv, Ukraine, e-mail: tugay.anatoliy@gmail.com \\ 2 Taras Shevchenko National University of Kyiv, \\ Kyiv, Ukraine, e-mail: zadorozhna_lida@ukr.net \\ ${ }^{3}$ Schmalhausen Institute of Zoology, NASc of Ukraine, \\ Kyiv, Ukraine,e-mail: astromott@gmail.com
}

ABSTRACT. Current studies of extragalactic X-ray sources using data from orbital observatory XMMNewton are at the front line of X-ray astronomy. Resolution capacity of the observatory instruments enable to detect separate X-ray sources in the close galaxies. In this study we used data from recently published 4XMM-DR9 catalog. This catalog contains 550124 unique sources covering $2,85 \%$ of the sky. The main type of extended extragalactic X-ray source is hot halo of galaxy cluster. Such objects are important for astrophysics in the tasks of revealing dark matter distribution, galaxy formation and different cosmology studies.

At the same time, some images of the galaxy clusters contain small scale pointlike X-ray sources scattered around the clusters or their halos. In many cases the nature of such objects is not clear yet and require more detailed studies. Furthermore, energy flux detection threshold of such objects is limited to a great extend not only by the instruments on board of the XMMNewton observatory but the natural sky background radiation, which is at the level of $10^{-13} \mathrm{Wm}^{-2} \mathrm{sr}^{-1}$ both for XMM cameras and the sky background.

Using Hyperleda database we revealed 16 galaxy clusters among the bright XMM sources. Images of the two galaxy clusters demonstrate bright galaxy cores. These clusters are galaxy group NGC 507 and Coma cluster where nucleus of galaxy NGC 4889 was clearly detected. We also analyzed X-ray images of 14 other X-ray clusters but had not found AGNs there.

Out of the above mentioned 16 clusters in the 7 of them we have found 30 pointlike X-ray sources. These sources are presumably mainly AGNs within these clusters. From the other side, they could be also more distant X-ray objects.

Keywords: Galaxiess's X-ray emission, XMMNewton, HyperLeda, Active Galaxy Nucleus, galaxy halo, galaxy clusters.

АНОТАЦЯ Сучасні дослідження позагалакти- чних джерел рентгенівського випромінення за допомогою даних, які отримані орбітальною обсерваторією XMM-Newton знаходяться на передовій лініі рентгенівської астрономіі. Роздільна здатність приладів обсерваторії дозволяє виявляти окремі джерела рентгенівських променів у близьких галактиках. У цьому дослідженні ми використовували дані нещодавно опублікованого каталогу 4XMM-DR9. Цей каталог містить 550124 унікальних джерел, що охоплюють 2,85\% неба. Основним типом протяжного позагалактичного джерела рентгенівського випромінювання є гаряче гало скупчення галактик. Такі об'єкти є важливими для астрофізики в задачах виявлення розподілу темної матерії, утворення галактик та різних космологічних досліджень.

У той же час, деякі зображення скупчень галактик містять точкові рентгенівські джерела невеликого розміру, які розсіяні навколо скупчень або їх гало. У багатьох випадках природа таких об'єктів ще не ясна і вимагає більш детальних досліджень. Крім того, поріг детектування потоку енергії таких об'єктів обмежений не тільки приладами на борту обсерваторії XMM-Newton, але й природним фоном випромінювання неба в рентгенівському діапазоні, яке знаходиться на рівні $10^{-13} \mathrm{BT}_{\mathrm{m}} \mathrm{M}^{-2} \mathrm{cp}^{-1}$ як для XММ камер, так і для фону неба.

Використовуючи базу даних Hyperleda, ми виявили 16 скупчень галактик серед яскравих джерел ХММ. Зображення двох скупчень галактик демонструють яскраві ядра галактик. Ці скупчення - група галактик NGC 507 та скупчення Coma, де ядро галактики NGC 4889 було чітко виявлено. Ми також проаналізували рентгенівські зображення інших рентгенівських кластерів проте АЯГ там не було знайдено.

Серед 16 згаданих вище скупчень у 7 ми знайшили 30 точкових джерел рентгенівського випромінювання. Ці джерела, імовірно, в основному є AGN в межах цих кластерів. 3 іншого боку, 
Table 1: Counts of discrete sources in X-ray clusters

\begin{tabular}{|c|c|c|}
\hline N & BCG & Sources \\
\hline 1 & 6dFGS gJ034253.0-533753 & 0 \\
2 & ESO 156-8 & 1 \\
3 & ESO 383-76 & 0 \\
4 & ESO 444-46 & 0 \\
5 & ESO 444-76 & 0 \\
6 & M 87 & 1 \\
7 & NGC 507 & 9 \\
8 & NGC 708 & 6 \\
9 & NGC 1129 & 0 \\
10 & NGC 1650 & 2 \\
11 & NGC 3311 & 6 \\
12 & NGC 4696 & 0 \\
13 & NGC 4756 & 5 \\
14 & NGC 4761 & 0 \\
15 & NGC 4889 & 0 \\
16 & NGC 5044 & 0 \\
\hline
\end{tabular}

такі точкові джерела можуть бути також і більш віддаленими рентгенівськими об'єктами.

Ключові слова: Рентгенівське випромінення галактик, XMM-Newton, HyperLeda, Активні ядра галактик, Галактичне гало, галактичні кластери.

\section{Introduction}

X-Ray observations are of a great importance for extragalactic astronomy. A number of different active objects could be currently detected only in X-ray band. During decades of X-Ray observations using orbital observatory XMM-Newton there was established a large data base which is continuously updated and accessible e.g. through Hyperleda database. Recently made available version 4XMM-DR9 (Webb et al., 2020) contains more than 500 thousand sources.

Most of X-ray emitting galaxies are more likely to have AGNs (Tugay \& Vasylenko, 2011), but this statement should be verified. Galaxy clusters are another type of extragalactic X-ray sources and at the same time are important tracers of large-scale structure of the universe. Main morphology features of LSS may be characterized by filaments (Tempel, 2013; Tugay, 2014) but the clusters are much more visible especially in X-ray band. Possible coorelation of X-ray clusters orientation with LSS features was considered in (Tugay et al., 2016). For complex LSS studies both optical and X-ray observations are needed as well as data on peculiar motions of the galaxies to a maximum possible sample size (Parnovsky \& Tugay, 2005). In the scope of this study the aim of this paper was to analyze X-ray clusters and search for point-like sources in them. Later we are going to

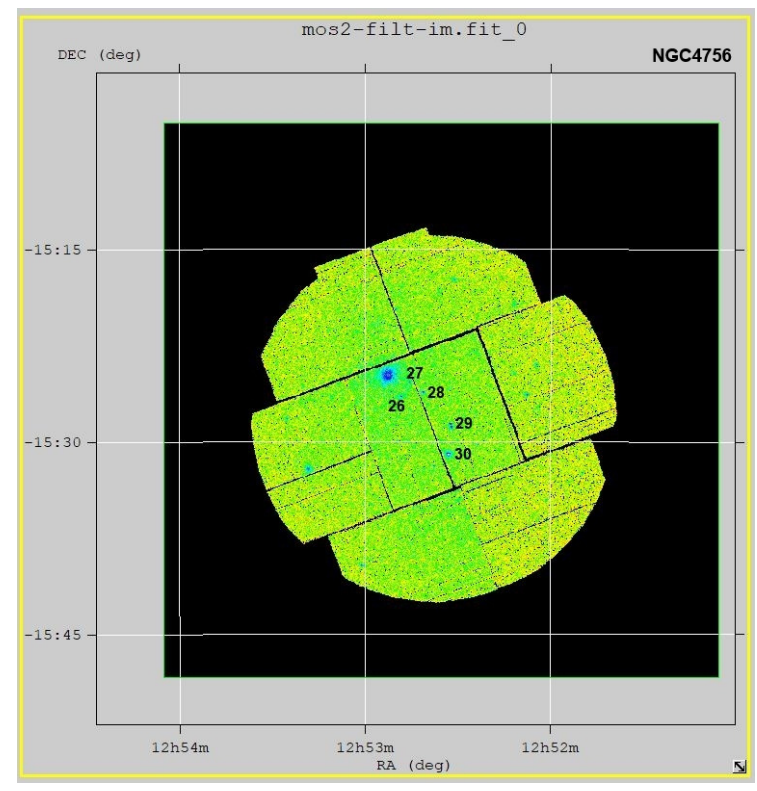

Fig. 1: NGC4756 and 5 detected point-like X-ray sources

study much more faint X-ray extragalactic sources and compare them with the sources found in this paper.

\section{Methodology}

XMM-Newton observatory is definitely the best facility to study large samples of X-ray sources. It holds on board three European Photon Imaging cameras (MOS1, MOS2 and PN) capable to obtain images, spectra and lightcurves of the studied objects. MOS1 and MOS2 cameras are suitably designed to build images so in this study we selected their data. Detection energy interval of MOS cameras is in the range of $0.2 \mathrm{keV}$ to $12 \mathrm{keV}$. To select bright X-ray clusters we used Xgal sample of extragalactic X-ray sources (Tugay, 2014). All sources with $\mathrm{F}_{X}>10^{-13} \mathrm{Wm}^{-2} \mathrm{sr}^{-1}$ were identified with Simbad data base ${ }^{1} .16$ clusters were found with at least one X-ray galaxy inside. For data and image processing software we used fits viewer available from NASA High Energy Astrophysics Science Archive Research Center ${ }^{2}$. The list of our sample is presented at Table 1 . We refer to each cluster by its brightest galaxy (BCG).

\section{Results}

Images analysis revealed a number of the point-like sources in a relative angular proximity to the known and reliably identified X-ray sources and their X-ray environment. Such a distance in analysed sample is nearly up to the size of 10 ' which corresponds to radius

\footnotetext{
${ }^{1}$ http://simbad.u-strasbg.fr/simbad/

${ }^{2}$ https://heasarc.gsfc.nasa.gov/docs/software/ftools/fv /
} 


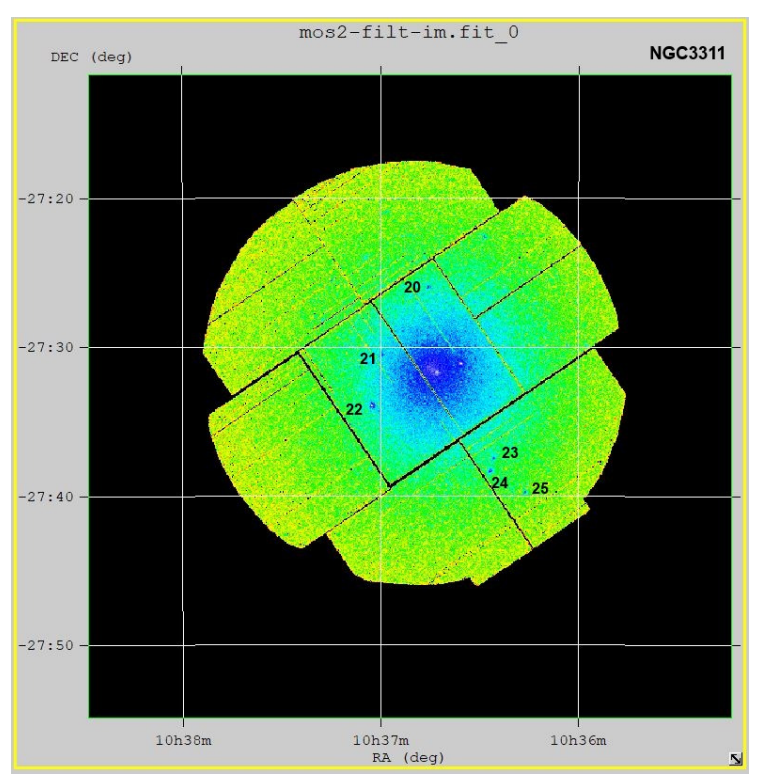

Fig. 2: NGC3311 and 6 detected point-like X-Ray sources

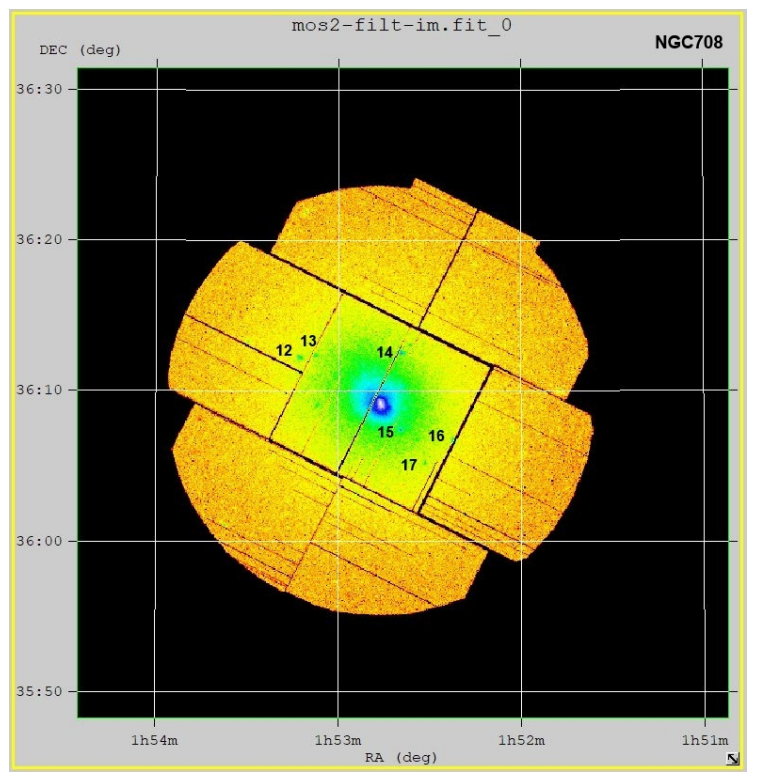

Fig. 3: NGC708 and 5 detected point-like X-ray sources

of the largest X-ray haloes. Some examples of the detected point-like sources are presented on Figs. 1 to 3. Numbers of detected sources around each BCG are given in Table 1. Detected point-like X-Ray sources coordinates are given in the Table 2 .

\section{Conclusion}

Performed study of the currently available data enabled to reveal 30 point like X-ray objects around 7 NGC and ESO catalogue objects. Further studies of their nature and properties will be useful for models of galaxy evolution.
Table 2: Coordinates of discrete sources in X-ray clusters

\begin{tabular}{|c|c|c|c|}
\hline $\mathrm{N}$ & BCG & $\mathrm{RA}$ & DEC \\
\hline 1 & ESO 156-8 & $3 \mathrm{~h} 41 \mathrm{~m} 44.20 \mathrm{~s}$ & $-53: 42: 19.46$ \\
\hline 2 & M 87 & $12 \mathrm{~h} 30 \mathrm{~m} 58.47 \mathrm{~s}$ & $12: 11: 21.96$ \\
\hline 3 & NGC 507 & $1 \mathrm{~h} 23 \mathrm{~m} 11.70 \mathrm{~s}$ & $33: 27: 48.86$ \\
\hline 4 & NGC 507 & $1 \mathrm{~h} 23 \mathrm{~m} 24.98 \mathrm{~s}$ & $33: 25: 24.82$ \\
\hline 5 & NGC 507 & 1h23m44.86s & $33: 26: 08.52$ \\
\hline 6 & NGC 507 & $1 \mathrm{~h} 23 \mathrm{~m} 54.67 \mathrm{~s}$ & $33: 23: 39.22$ \\
\hline 7 & NGC 507 & $1 \mathrm{~h} 22 \mathrm{~m} 58.52 \mathrm{~s}$ & $33: 22: 47.18$ \\
\hline 8 & NGC 507 & $1 \mathrm{~h} 23 \mathrm{~m} 10.95 \mathrm{~s}$ & $33: 19: 45.88$ \\
\hline 9 & NGC 507 & 1h23m06.30s & $33: 19: 32.86$ \\
\hline 10 & NGC 507 & 1h23m07.09s & $33: 19: 23.33$ \\
\hline 11 & NGC 507 & $1 \mathrm{~h} 23 \mathrm{~m} 10.99 \mathrm{~s}$ & $33: 10: 51.15$ \\
\hline 12 & NGC 708 & $1 \mathrm{~h} 53 \mathrm{~m} 12.59 \mathrm{~s}$ & $36: 12: 16.36$ \\
\hline 13 & NGC 708 & $1 \mathrm{~h} 53 \mathrm{~m} 07.63 \mathrm{~s}$ & $36: 12: 25.44$ \\
\hline 14 & NGC 708 & $1 \mathrm{~h} 52 \mathrm{~m} 39.13 \mathrm{~s}$ & $36: 12: 31.65$ \\
\hline 15 & NGC 708 & $1 \mathrm{~h} 52 \mathrm{~m} 39.13 \mathrm{~s}$ & $36: 07: 22.70$ \\
\hline 16 & NGC 708 & $1 \mathrm{~h} 52 \mathrm{~m} 22.30 \mathrm{~s}$ & $36: 06: 46.64$ \\
\hline 17 & NGC 708 & $1 \mathrm{~h} 52 \mathrm{~m} 31.96 \mathrm{~s}$ & $36: 05: 13.71$ \\
\hline 18 & NGC 1650 & $4 \mathrm{~h} 45 \mathrm{~m} 11.45 \mathrm{~s}$ & $-15: 46: 08.04$ \\
\hline 19 & NGC 1650 & $4 \mathrm{~h} 44 \mathrm{~m} 52.06 \mathrm{~s}$ & $-15: 48: 01.20$ \\
\hline 20 & NGC 3311 & $10 \mathrm{~h} 36 \mathrm{~m} 45.29 \mathrm{~s}$ & $-27: 25: 54.45$ \\
\hline 21 & NGC 3311 & $10 \mathrm{~h} 36 \mathrm{~m} 59.29 \mathrm{~s}$ & $-27: 30: 34.85$ \\
\hline 22 & NGC 3311 & $10 \mathrm{~h} 37 \mathrm{~m} 02.15 \mathrm{~s}$ & $-27: 33: 50.38$ \\
\hline 23 & NGC 3311 & $10 \mathrm{~h} 36 \mathrm{~m} 25.70 \mathrm{~s}$ & $-27: 37: 26.24$ \\
\hline 24 & NGC 3311 & $10 \mathrm{~h} 36 \mathrm{~m} 26.57 \mathrm{~s}$ & $-27: 38: 21.70$ \\
\hline 25 & NGC 3311 & $10 \mathrm{~h} 36 \mathrm{~m} 16.02 \mathrm{~s}$ & $-27: 39: 46.20$ \\
\hline 26 & NGC 4756 & $12 \mathrm{~h} 52 \mathrm{~m} 48.39 \mathrm{~s}$ & $-15: 26: 26.79$ \\
\hline 27 & NGC 4756 & $12 \mathrm{~h} 52 \mathrm{~m} 45.18 \mathrm{~s}$ & $-15: 25: 17.28$ \\
\hline 28 & NGC 4756 & $12 \mathrm{~h} 52 \mathrm{~m} 41.13 \mathrm{~s}$ & $-15: 26: 06.48$ \\
\hline 29 & NGC 4756 & $12 \mathrm{~h} 52 \mathrm{~m} 32.08 \mathrm{~s}$ & $-15: 26: 42.14$ \\
\hline 30 & NGC 4756 & $12 \mathrm{~h} 52 \mathrm{~m} 33.02 \mathrm{~s}$ & $-15: 30: 55.24$ \\
\hline
\end{tabular}

Acknowledgements. This study was conducted using the data from recently updated XMM-Newton 4XMM-DR9 catalogue. We acknowledge the usage of the HyperLeda database (http://leda.univ-lyon1.fr).; SIMBAD Astronomical Database - CDS (Strasbourg) http://simbad.u-strasbg.fr/simbad/

\section{References}

Makarov D., Prugniel P., Terekhova N. et al.: 2014, A. \& A., 570A, 13 .

Mingo B., Watson M.G., Rosen S.R. et al.: 2016, MNRAS, 462, 2631.

Parnovsky S.L., Tugay A.V.: 2005, astro-ph/0510037.

Tugay A.V. \& Vasylenko A.A.: 2011, Odessa Astron. Publ., 24, 72.

Tugay A.V.: 2014, IAU Symposium, 304, 168.

Tugay A.V., Dylda S.S., Panko E.A.: 2016, Odessa Astron. Publ., 29, 34.

Webb N.A., Coriat M., Traulsen I. et al.: 2020, A. \& A., accepted for publication, arXiv:2007.02899.

Watson M.G., Schröder A.C., Fyfe D. et al.: 2009, A. \& A., 493, 339 . 